This PDF is a selection from an out-of-print volume from the National Bureau of Economic Research

Volume Title: Tax Policy and the Economy, Volume 3

Volume Author/Editor: Lawrence H. Summers, editor

Volume Publisher: MIT Press

Volume ISBN: 0-262-06126-0

Volume URL: http://www.nber.org/books/summ89-1

Conference Date: November 15, 1988

Publication Date: 1989

Chapter Title: Budget Deficits, Tax Incentives, and Inflation:

A Surprising Lesson from the 1983-1984 Recovery

Chapter Author: Martin Feldstein, Douglas W. Elmendorf

Chapter URL: http://www.nber.org/chapters/c10943

Chapter pages in book: (p. 1 - 24) 


\section{BUDGET DEFICITS, TAX INCENTIVES, AND INFLATION: A SURPRISING LESSON FROM THE 1983-1984 RECOVERY}

\section{Martin Feldstein}

Harvard University and NBER

\section{Douglas W. Elmendorf}

Harvard University and NBER

In November 1982, the unemployment rate reached 10.6 percent, the trough of the worst recession of the postwar period. During the next twenty-four months, the unemployment rate fell by 3.5 percentage points and real GNP expanded by 11.9 percent. This stronger-thannormal expansion was accompanied by a declining rate of inflation; the annualized rates of increase of the GNP deflator fell from 3.6 percent in the fourth quarter of 1982 to 3.0 percent in the fourth quarter of 1984 .

The saying that failure is an orphan, while success has many selfproclaimed fathers can be applied to business cycles in general and to this one in particular. The battle over paternity is joined here by supply siders, by Keynesian fiscalists, and by monetarists.

Some supply-side economists argue that the recovery reflected the favorable incentive effects on individual work effort of the January 1983 reductions in personal tax rates. In the extreme version of this view,

This paper was prepared for the NBER conference "Tax Policy and the Economy" held in Washington, D.C., on 15 November 1988. We are grateful to Greg Mankiw and Lawrence Summers for helpful comments. 
workers reduced their labor supply when the prospective tax cuts were legislated in 1981, preferring to consume more of their lifetime leisure when aftertax wages were relatively low and then to increase their work effort after the tax rate reductions raised net wages.

The Keynesian fiscalists regard the 1983-1984 expansion as a traditional demand-determined recovery driven by increased defense spending and by the rise in consumer demand that resulted from the personal tax reductions. We use the term Keynesian fiscalists to emphasize that these economists disregard the role of monetary policy in the expansion.

Finally, monetarists point to the sharp reversal of the Federal Reserve's policy in the summer of 1982, some six months before the business cycle trough. With inflation falling rapidly, the rate of change of the real money stock increased even more rapidly than the rate of change of the nominal money stock. The Fed cut the discount rate sharply throughout the summer and fall, and short-term market rates dropped dramatically.

In an earlier report on this research, Feldstein (1986a) argued that none of these claims provides an adequate explanation of the fasterthan-normal recovery in real GNP. He suggested an alternative analysis of how the changes in monetary policy, budget deficits, and tax incentives for investment acted together to produce the unusually strong recovery. The present paper elaborates on that previous discussion and presents evidence in support of that alternative view.

Before turning to the evidence, it will be useful to summarize the explanation that the evidence suggests:

1. The increased employment and output did not reflect an increase in the desire to work but was the result of an increased demand for labor, which permitted unemployed job-seekers to return to work. While the unemployment rate fell from 10.6 percent to 8.3 percent in the first year of the expansion, labor force participation rates showed virtually no movement. ${ }^{1}$

2. The sharp change in monetary policy was the driving force in the expansion of nominal demand; the rapid expansion of nominal GNP can be explained by the shift in monetary policy, without any reference to changes in fiscal and tax policy. The composition of the GNP change also suggests the dominance of monetary policy.

3. However, the growth of real GNP was more rapid than would have

1 The labor force participation rate for women 20 years and older increased from 52.9 percent in November 1982, the trough of the recession, to only 53.2 percent in November 1983, one year into the expansion. The corresponding rate for men actually fell from 78.8 percent to 78.4 percent during the same period. And the labor force participation rate for all people aged 16 to 19 fell also, from 54.5 percent to 53.3 percent. 
been expected on the basis of the rise in total nominal spending, and the increase in the price level was correspondingly slower. The most likely cause of this favorable division of the nominal GNP increase was the sharp rise in the dollar that occurred at this time.

4. Although part of the dollar's rise can be attributed to the successful anti-inflationary monetary policy, the dollar's value also increased because of the rise in real interest rates that resulted from the combination of increased budget deficits and the improved tax incentives for investment in equipment and structures. The changes in fiscal and tax policy thus contributed to the unusually strong real GNP growth by causing inflation to be less than it otherwise would have been. Stated differently, with monetary policy given, the fiscal expansion temporarily reduced inflation and thereby contributed to temporarily stronger real GNP growth.

5. The tax incentives for business fixed investment also affected the composition of the recovery in real GNP. Despite the rise in real interest rates, the recovery was characterized by a much greater than normal increase in business investment, while the increase in consumer spending was similar to the increase in previous recoveries.

Section 1 of this paper presents the evidence that the rise in nominal GNP can be explained by the shift in monetary policy. Detailed evidence on the relative strength of different sectors, presented in section 2 , supports the importance of the change in monetary policy and interest rates and implies that neither increased government spending nor personal tax cuts was a significant factor in the demand recovery. The third section shows that real GNP grew faster than might have been anticipated on the basis of past experience but that this discrepancy can be explained by the favorable effect of the rising dollar on the overall level of domestic prices. There is a brief concluding section.

We are, of course, aware that the evidence that we present may be subject to different interpretations. We hope that our analysis will encourage others to provide additional tests of our proposed explanation of the recovery of 1983-1984 and of the implied theory of the interaction of monetary, tax, and fiscal policies.

\section{THE RISE IN NOMINAL GNP}

The path of nominal GNP changed dramatically at the end of 1982. After rising at a rate of only 3.0 percent from the fourth quarter of 1981 through the fourth quarter of 1982, nominal GNP rose 9.8 percent in 1983 and 8.2 percent in 1984 . The seasonally adjusted quarterly rates of 
TABLE 1

Effects of Monetary and Fiscal Policies on Nominal GNP Growth

\begin{tabular}{|c|c|c|c|c|c|c|c|}
\hline \multicolumn{4}{|c|}{ Specifications } & \multirow{2}{*}{\multicolumn{4}{|c|}{1982}} \\
\hline & \multirow{2}{*}{$\begin{array}{c}\text { Money } \\
\text { variables }\end{array}$} & \multirow{2}{*}{$\begin{array}{c}\text { Fiscal } \\
\text { variables }\end{array}$} & \multirow{2}{*}{$\begin{array}{c}\text { Debt } \\
\text { erosion } \\
\text { adjustment }\end{array}$} & & & & \\
\hline & & & & Q1 & Q2 & Q3 & $\mathrm{Q} 4$ \\
\hline & & & & \multicolumn{4}{|c|}{ Actual growth } \\
\hline (1) & & & & -.001 & $\begin{array}{r}.015 \\
\text { Forecas } \\
\end{array}$ & $\begin{array}{r}.006 \\
\text { esiduals }\end{array}$ & .010 \\
\hline (2) & M2 & No & - & -.025 & -.009 & -.015 & -.011 \\
\hline (3) & M2 & Yes & No & -.027 & -.012 & -.022 & -.020 \\
\hline (4) & M2 & Yes & Yes & -.025 & -.009 & -.017 & -.015 \\
\hline (5) & M2 Adj. & No & - & -.025 & -.009 & -.015 & -.011 \\
\hline (6) & M2 Adj. & Yes & No & -.027 & -.012 & -.022 & -.020 \\
\hline (7) & M2 Adj. & Yes & Yes & -.025 & -.099 & -.017 & -.015 \\
\hline
\end{tabular}

All figures relate to seasonally adjusted quarterly rates of change. See text for definitions of variables and procedures. The standard errors of the forecast residuals are all 0.010 for single quarters, between 0.020 and 0.023 for one-year cumulations, and between 0.028 and 0.040 for two-year cumulations.

change of nominal GNP are presented for 1982:1 through 1984:4 in row 1 of Table 1.

The simplest explanation of this increase is the change of monetary conditions during the preceding year. The rate of increase of the real money stock (that is, the difference between the rate of increase of M2 and the rate of increase of the GNP deflator) rose from 2.2 percent in the first half of 1982 to 5.0 percent during the second half of the year. ${ }^{2}$ Real short-term interest rates dropped dramatically; the three-month Treasury bill rate plummeted from over 12 percent in June 1982 to 8 percent within three months. The Federal Reserve reduced the discount rate in parallel with very little delay, cutting it from 12 percent in June to 10 percent in September and then to 8.5 percent by the end of the year.

To assess the proposition that the 1983-1984 expansion of nominal demand can be explained without reference to fiscal changes, we present two types of evidence. The first, presented in Table 1, shows the forecast errors in predictions of nominal GNP in 1983-1984 based on distributed lags of money alone and of money and alternative fiscal variables. The second, presented in Table 2, shows formal F-tests of the significance of the fiscal variables in the explanation of changes in nominal GNP both in a long sample and in the recent quarters.

2 The rate of growth of M1 increased from 4.6 percent in the first half of 1982 to nearly 12 percent in the second half of 1982 . The rate of growth of M2 rose from 7.8 percent to 9.6 percent. 
TABLE 1

(continued)

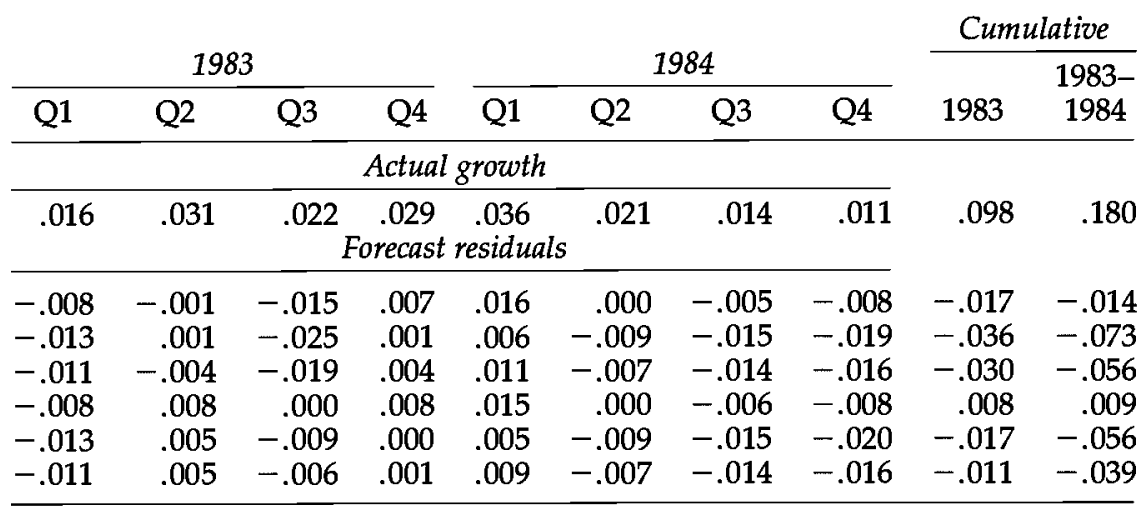

\subsection{An Analysis of Forecast Residuals}

The forecast residuals associated with an equation relating nominal GNP growth to past changes in the money stock (nominal M2) show that the increases in nominal GNP in 1982, 1983, and 1984 are fully predicted without any reference to shifts in fiscal policy. More specifically, we estimated the relation between the quarterly change in the logarithm of nominal GNP and three lagged values of the change in the logarithm of M2. ${ }^{3}$ The equation was estimated by ordinary least squares for the period from the first quarter of 1960 through the business cycle peak in the third quarter of 1981 . The equation was then used to predict the rates of growth of nominal GNP in the out-of-sample period beginning with the fourth quarter of 1981.

Row 2 of Table 1 presents the forecast residuals, that is, the difference between the actual quarterly GNP growth rates and the rates predicted on the basis of the lagged changes in money. For comparison, the table includes the forecast errors for 1982, the last four quarters of the recession. The standard error of each of these quarterly forecasts is approximately 0.01 , or one percentage point of nominal GNP.

The striking thing about the errors in the out-of-sample forecasts for the recovery period is that they are generally negative, indicating that the actual rise in nominal GNP was less than the rise predicted by the historic relation between nominal GNP and money. During the first two

3 All of the data used in this paper were drawn from the Data Resources, Inc. database, updated for data revisions through September 1988. 
years of the recovery, the forecast error was negative five times; however, only two of the forecast errors (one positive and one negative) exceeded the standard error. The cumulative forecast error for the first four quarters of the recovery was negative and was 1.7 percent of GNP, slightly less than the four-quarter forecast standard error of 2.0 percent of GNP. The forecast error for the first eight quarters was also negative and, at 1.4 percent of GNP, less than the associated standard error of 2.9 percent of GNP. There is no "surprisingly strong" rise in total nominal GNP that needs to be explained by the budget deficit or by tax law changes. ${ }^{4}$

We would, of course, be the first to acknowledge that an equation linking nominal GNP growth to money growth alone is an extremely simplified model. But we regard its predictions and the associated forecast residuals as useful benchmarks, and we reject as unnecessarily nihilistic the view of economists such as Friedman (1988) that the velocity fluctuation of the 1980s means that nothing can be learned from quantity relationships like those considered here. First, we are studying growth rates and not relations in levels, so a one-time shift in velocity of the type that occurred in 1982 would not affect the residuals for 1983 or 1984 from our equations. Second, if velocity fell sharply in 1982 because of suddenly expansionary monetary policy-acting through a sharp fall in interest rates, as Poole (1988) has suggested-then our emphasis on the importance of monetary policy to the recovery is not misplaced. Moreover, the increase in nominal GNP from 1982 to 1983 predicted by our equations represents a major part of the increase in actual growth of nominal GNP between those years.

Adding measures of fiscal policy to the basic equation does not improve the explanation of the rapid growth of nominal GNP in 1983 and 1984. On the contrary, since fiscal policy was "expansionary" at this time, the forecasts that include fiscal variables overpredict GNP growth by an even greater margin, thereby increasing the absolute size of the forecast residuals. The basic fiscal variables in our expanded equation are the ratios of cyclically-adjusted tax revenue and government outlays to cyclically-adjusted GNP, taken from Holloway (1986), and each repre-

\footnotetext{
${ }^{4}$ It might be argued that the residuals in 1983, although negative, are smaller absolutely than the residuals of 1982, suggesting that "something" had made nominal GNP grow more rapidly in 1983 than would have been predicted on the basis of lagged money alone. There is no way to test this view that the unobserved and unobservable shock that caused velocity to drop in 1982 persisted into 1983 and was offset by fiscal policy. We take the more conventional view that 1982 , in which velocity declined, was the abnormal year and that there was no a priori reason to expect the negative disturbance to persist into 1983 . More formally, the residuals for 1983 and 1984 should be tested against the null hypothesis of zero and not against the values for 1982.
} 
sented by three lagged values. Since the difference between these measures of receipts and outlays is equal to the cyclically-adjusted deficit as a fraction of GNP in each quarter, the coefficient values could make this equivalent to a distributed lag of deficit-to-GNP ratios.

Row 3 of Table 1 reports the forecast residuals based on an equation in which fiscal variables are added to the distributed lag of M2 growth rates. The cumulative forecast error is 3.6 percent of GNP for the first four quarters of the recovery and 7.3 percent of GNP for the first eight quarters. The point to be stressed is that the monetary variables more correctly explain the rise in nominal GNP without reference to the fiscal variables.

We are aware, of course, of the usual arguments that equations of this type understate the importance of fiscal policy (for example, Blinder and Solow, 1974). In the current context, a stronger fiscal effect would by itself cause an even greater overprediction of GNP growth. While not suggesting that the estimated coefficients are appropriate estimates of true reduced form parameters, we emphasize that they imply no support for a role for fiscal policy in explaining the nominal GNP expansion in 1983-1984.

The results represented by these two equations are not sensitive to the measurement of monetary and fiscal policies. As part of our sensitivity analysis, we redefined the government outlay variable to exclude the component of government interest outlays that merely compensates bondholders for the inflation erosion of the debt. ${ }^{5}$ The result, shown in row 4 , is similar to the basic estimates of row 3 .

We also tested the sensitivity of the results to the change in bank regulations that shifted the demand for money in 1983. The changes in regulations that took effect at the start of 1983, including the introduction of national NOW accounts and changes in the interest rate ceilings, caused an increase in the demand for M1 and M2 balances. The Fed accommodated this increase, permitting M2 to rise at a 16.1 percent annual rate. A mechanical interpretation of the relation between nominal GNP and the increase in the money stock may overstate the expansionary effect of monetary policy. ${ }^{6}$ We have therefore re-estimated the analysis of equa-

\footnotetext{
${ }^{5}$ We construct an inflation-adjusted outlay measure by subtracting the product of the quarterly change in the GNP deflator and the stock of outstanding government debt at the beginning of the quarter from the traditional measure of outlays.

${ }^{6}$ Federal Reserve Chairman Volcker and the Federal Open Market Committee emphasized in testimony and official statements on several occasions that the M1 growth rates from 1982:4 through 1983:2 and the M2 growth rates in 1983:1 and 1983:2 were really adjustments to the new regulatory environment and therefore not directly comparable to past increases in the money stock. See also Economic Report of the President, 1984, Chapter 1.
} 
tions corresponding to rows 2 through 4 with an adjusted money stock constructed to eliminate the effect of the deregulation-induced shift in the demand for money balances. More specifically, the growth rates of M2 in 1983:1 and 1983:2 are reduced to smooth the path of M2 from 1982:4 to $1983: 3$ by replacing the actual growth rates during the two transitional quarters by the average of the prior and subsequent quarter growth rates. The effect is to leave the level of M2 3.5 percent lower beginning in 1983:3.

The results for this adjusted M2 variable are shown in rows 5 through 7. The forecast residuals for the basic equation with no fiscal variable (row 5) are representative of the effect of using the adjusted money stock. The equation no longer systematically overpredicts the growth of nominal GNP. Three of the forecast residuals are positive, three are negative, and two are zero; only one is larger than the standard error. The cumulative forecast error for four quarters and eight quarters are 0.008 and 0.009 , both substantially smaller than the corresponding standard errors. Including the fiscal variables with the adjusted money stock once again raises the forecast growth of nominal GNP, by approximately the same amounts as in the equations represented by rows 3 and 4 . These equations again overpredict GNP growth, but by less than the equations using the raw money values. In short, the adjusted money stock variable provides better point estimates, but the choice between adjusted and unadjusted money stock variables does not alter the conclu- sion that the rise of nominal GNP in 1983-1984 can be explained without reference to the changes in tax receipts and outlays.

We have also examined the residuals based on equations using M1 and adjusted M1 instead of M2 and adjusted M2. The results were qualitatively similar, although not identical. In general, the underprediction of nominal GNP.growth was worse in the M1 equations than in the M2 equations. The addition of the fiscal variables (inflation-adjusted or not) magnified the negative residuals.

The analysis has also been repeated with the sample restricted to begin in 1968:1 instead of 1960:1. We did this because some authors (for example, Friedman, 1986 and 1988) have stressed that the relation between the monetary aggregates and nominal GNP may have changed in the mid-1960s. We find that the results based on the shorter sample are essentially the same as those based on the full sample.

\subsection{The Incremental Explanatory Power of Fiscal Variables}

The conclusion that the expansion of nominal GNP in the 1983-1984 recovery can be explained without reference to fiscal policy is consistent with a long line of monetarist thinking and with econometric evidence in 
the St. Louis equation framework of Andersen and Jordan (1968). Both the theory and the empirical research remain controversial and are likely to continue to be controversial in the future.

Although Blinder and Solow (1974) and others have argued that the coefficient estimates and statistical tests of the impact of fiscal policy in the Andersen-Jordan framework are biased, McCallum (1986) has recently provided a strong defense of these procedures. We will not enter into the debate about whether the tests of the efficacy of fiscal policy based on this framework are correct or not. But for those who want to see the evidence for the most recent recovery within this framework, formal tests of the relevance of the fiscal variables as determinants of the growth of nominal GNP are presented in Table 2. The tests are based on estimating the nominal GNP growth equations for the entire period from 1960:1 through 1985:4 and testing whether the addition of the fiscal variables reduces the sum of squared residuals. ${ }^{7}$ We allow for a change in the constant term and in the coefficients on the distributed lag on money after 1981:3. We test separately for the effect of the fiscal variables in the early sample (through 1981:3) and in the late sample (from 1981:4 to 1985:4); in Table 2, Test 1 refers to the effect of the fiscal variables during the early sample, while Test 2 refers to the effect of the fiscal variables during the late period only. ${ }^{8}$ Separate tests are presented with and without adjustment to money stocks and with and without the inflation adjustment to the fiscal variables.

Consider first the test based on the unadjusted definitions of the money and fiscal variables. Test 1 , for the early sample period, has an Fstatistic of 1.30 (shown on the first line of Table 2), which corresponds to a statistically insignificant probability level of 0.25 . Test 2 , for the later sample, has an F-statistic of 2.16, which because of the more-limited number of observations also corresponds to a statistically insignificant probability level.

The second line of Table 2 presents results when the government outlay variable is adjusted to eliminate the effect of debt erosion. When

7 Regressing the absolute value of the estimated residuals on a dummy variable for the period 1981:4 through 1985:4 (as suggested by Pindyck and Rubinfeld, 1981, p. 152) reveals significant heteroskedasticity. Therefore, we weight the observations using the inverse of the mean absolute value of the estimated residuals in the early and late samples and reestimate the equation.

${ }^{8}$ There are only sixteen observations in this later period, so there are few degrees of freedom in the estimation, and the 5 percent critical values for the F-statistics shown below will be fairly high. Although these exclusion tests therefore have low power, the Fstatistics are generally so small that even a powerful test would be very unlikely to reject the null hypotheses. See Fisher (1970, p. 365) for a discussion of testing similar hypotheses with insufficient degrees of freedom. 
TABLE 2

Tests of the Contribution of Fiscal Policy to Explaining Nominal GNP Growth

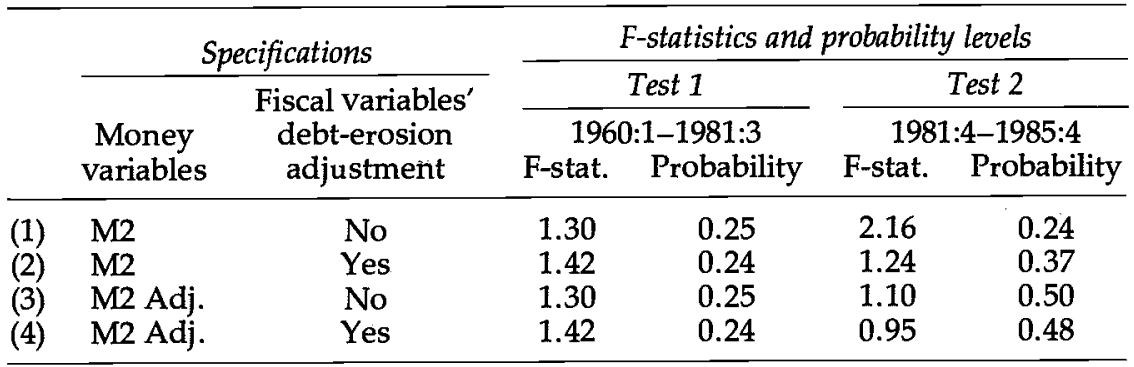

The F-statistics based on the adjusted fiscal variables have 8 and 78 degrees of freedom for Test 1 and have 8 and 4 degrees of freedom for Test 2; the statistics based on the adjusted fiscal variables have 4 and 86 degrees of freedom for Test 1 and have 4 and 8 degrees of freedom for Test 2.

the adjusted M2 money stock is used (lines 3 and 4 of Table 2), the fiscal variables are even less statistically significant in the late sample. ${ }^{9}$

Similar tests have been done (but are not shown) with adjusted and unadjusted M1 and with the period truncated to exclude the years before 1968. The results are quite similar to those presented here, with the probability levels even higher in the M1 equations. This reinforces the basic result of this analysis, that if fiscal variables contribute at all to the explanation of nominal GNP in the 1980s, it is only when no adjustment is made for the effects of inflation on the fiscal variables.

It is important to note that all of the results of this section apply to nominal GNP and do not consider the possible importance of fiscal policy to real GNP given the level of nominal GNP. In section 3, we examine the impact of recent fiscal policy on the division of nominal GNP growth into real GNP growth and inflation. First, however, we provide further evidence of the importance of monetary policy in the 1983-1984 recovery.

\section{THE COMPOSITION OF REAL GNP GROWTH IN THE RECOVERY}

The conclusion that the recovery of nominal GNP can be attributed to the increase in money growth and the fall in interest rates is also supported by an analysis of the relative rates of increase of the major compo-

9 The early sample tests are identical to those for the unadjusted money variables because the adjustment (described above) affects only quarters after 1981:3. 
nents of real GNP during the first two years of the recovery. Table 3 compares the growth rates of these real GNP components with the average growth rates for each of these components during the five previous postwar recoveries. ${ }^{10}$

Consider first the relative growth rates of total real GNP. The first column in the upper portion of Table 3 (labeled "Current") shows the seasonally adjusted quarterly growth rate of real GNP in each quarter from 1983:1 (Q1) through 1984:4 (Q8). The corresponding growth rate for the four quarters ending in 1983:4 is denoted "Y1," and the annual average growth rate for the eight quarters ending in 1984:4 is denoted "Y1-2." The average of the real GNP growth rates in the corresponding quarters ${ }^{11}$ of previous recoveries is shown in the second column (labeled "Avg." for Average), and the estimated standard error of that mean is shown in the third column.

These data show that real GNP rose 0.9 percent between the final quarter of 1982 and the first quarter of 1983, about half of the average first-quarter growth rate of 1.7 percent during the previous five recoveries. With a standard error of 0.3 , it can be said that the first quarter rise of the current recovery was significantly slower than the average of the past increases. Although this difference was reversed in the second and fourth quarters, for the year as a whole the rate of growth of real GNP at 6.5 percent was only slightly greater than the 6.0 percent average real GNP increase in the first four quarters of previous expansions; with a standard error of 0.8 percentage points, this difference is not statistically significant. The start of the second year of the current recovery was, however, much stronger than the average of the corresponding quarters of previous recoveries. As a result, the rate of increase of real GNP for the eight quarters as a whole was substantially greater than the average of previous recoveries: an average annual rate of 5.8 percent in comparison with the previous average of 4.8 percent and the previous standard error of 0.2 percentage points.

It might be argued that real GNP grew especially fast in the recovery because it had fallen especially far during the recession. Without entering

${ }^{10}$ These are the recoveries that began in 1954:3, 1958:3, 1961:2, 1971:1, and 1975:2. The analysis excludes the recovery that began in 1950:1 (which was unusual due to the Korean War) and the most recent 1980-1981 recovery, which was so short-lived that the next downturn occurred within two years of the start of the expansion. The real components of GNP are directly from the National Income and Product Accounts, with the exception of federal government military spending, which is converted to real values using the overall federal government spending deflator, because the military deflator is not available for the whole postwar period.

11 The quarters are aligned so that $\mathrm{Q} 1$ always corresponds to the first quarter after the trough of the recession, Q2 to the second quarter after the trough, and so on. 


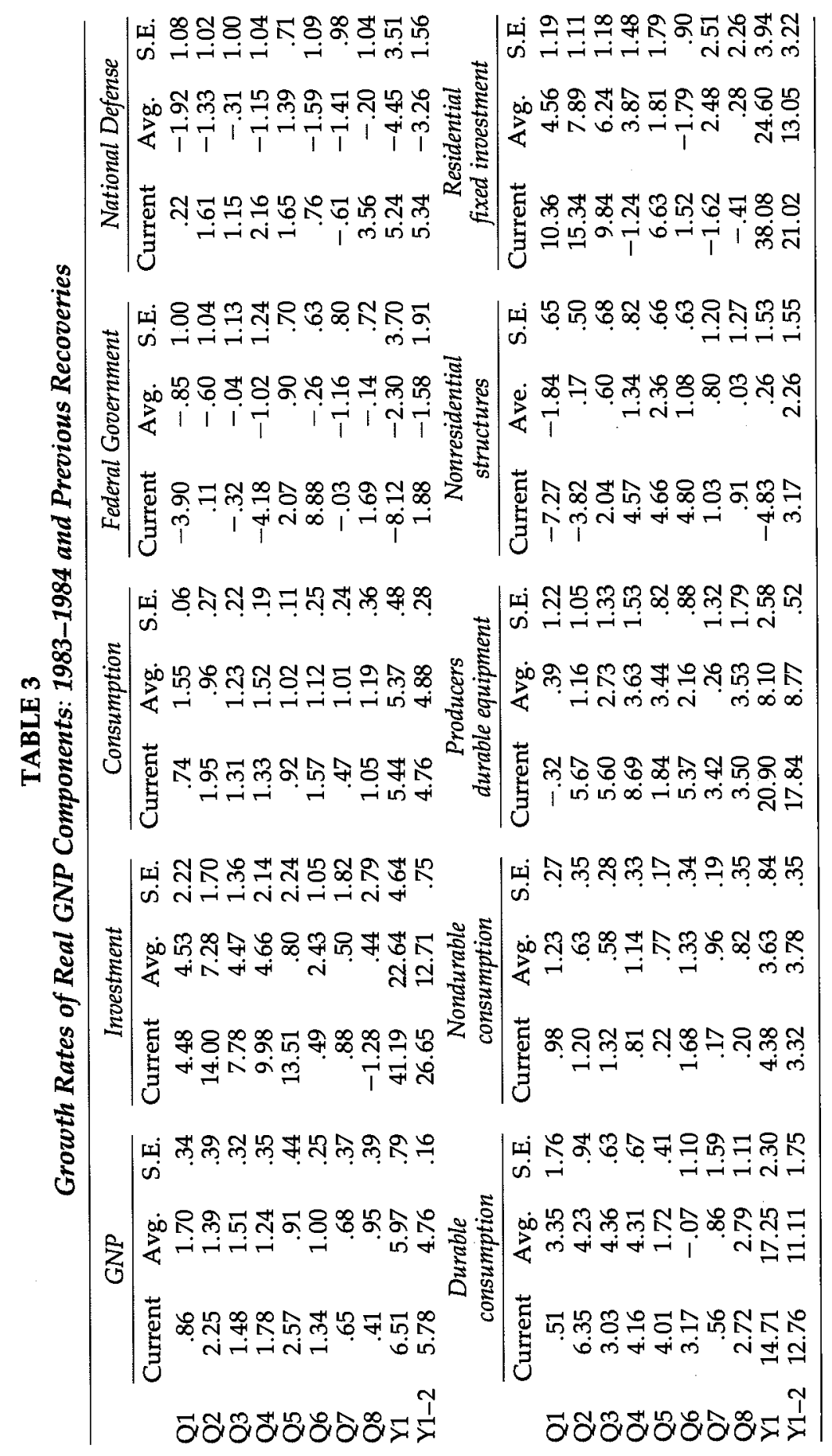


into the current macroeconomic debate about the time-series properties of real GNP, we note simply that there is no evidence for a correlation between the depth of a recession and the pace of the initial recovery; the GNP growth rates for the first four quarters of each postwar recovery (as well as for the first eight quarters) display no correlation with the depth of the recession as measured by the decline in real GNP between the previous cyclical peak and the trough.

When we examine the major components of real GNP, we find that the most striking difference between the 1983-1984 recovery and previous recoveries was in the strength of investment. By the second quarter of the recovery, the percentage increase in investment was approximately twice as great as the average for previous recoveries. For the first four quarters, investment rose $\mathbf{4 1 . 2}$ percent, in comparison with the $\mathbf{2 2 . 6}$ percent average in previous recoveries, an increase four times the standard error of 4.6 percentage points. For the two years as a whole, the average annual rate of increase of investment was 26.7 percent, versus the two-year average of 12.7 percent in previous recoveries. ${ }^{12}$

In contrast to the relatively powerful response of investment, the expansion of consumption was no stronger in this recovery than in previous recoveries. The figures in Table 3 show that the annual rate of increase of consumption in the four quarters of 1983 was 5.4 percent, almost exactly equal to the average rise in the first four quarters of previous recoveries. For the eight quarters through 1984:4, the annual rate of increase was 4.8 percent, slightly less than the 4.9 percent average in previous recoveries, but the difference is not as large as its standard error. ${ }^{13}$ Table 3 shows that this normal cyclical expansion of consumption in the 1983-1984 recovery characterized both durable and nondurable consumption.

The rate of increase in the federal government component of final demand was also not greater in the first year of the recovery than it had been at the same stage in previous recoveries. Real federal government purchases of goods and services ${ }^{14}$ actually fell by 8.1 percent, a substan-

12 Although the rapid rise of investment in the recovery might be thought attributable to particularly weak investment performance during the recession, investment in past recoveries was uncorrelated with investment during the preceding recessions.

13 Consumption relative to GNP was, in fact, stronger during the first year of the recovery than in previous recoveries. There is no evidence that the tax cut was offset by an equal rise in household saving, but only that the pace of increase in consumption was not unusually strong in this recovery, while the increase in investment was unusually rapid.

14 Note that this measure of government spending as a GNP component is very different from total government outlays, which include transfers as well as purchases of goods and services. 
tially larger decline than the 2.3 percent decline in the first four quarters of previous recoveries.

The initial decline and fairly standard two-year rise in real government purchases occurred despite a stronger-than-normal increase in military spending. Table 3 shows that military spending rose by 5.2 percent in 1983 but actually fell by an average of 4.5 percent in the first year of previous recoveries. For the two years as a whole, the 5.3 percent annual rise in military spending is significantly larger than the previous average of -3.3 percent. But although military spending is a large part of total federal government purchases of goods and services, the reductions in other purchases kept the overall contribution of increase in government spending relatively small.

The relatively sharp rise in investment and modest increases in consumption and in government spending support the conclusion of the previous section, that the 1983-1984 recovery was primarily due to an easing of monetary policy and not to budget policy. The relatively weak rise in consumption shows that the 1983-1984 recovery was not driven particularly by personal tax cuts, while the relatively slow rise in government demand shows it was also not driven particularly by government purchases of goods and services. Of course, all three major components of GNP contributed to the overall expansion of output, but the unusual feature of the 1983-1984 recovery was the unusually large rise in investment while consumption and government spending increases were close to their historic values. Moreover, the absolute rise in real investment during the first two years of the expansion (1982:4 to 1984:4) was greater than the combined increase of consumption and government outlays. In 1982 dollars, personal consumption expenditures rose \$202 billion, federal government purchases of goods and services rose $\$ 33$ billion, and investment rose $\$ 247$ billion. Fixed investment alone rose $\$ 146$ billion.

Monetary policy was certainly not the only factor influencing investment outlays. The major investment incentives enacted in the 1981 tax legislation also contributed to the strength of business investment. The maximum potential real net return on investment in plant and equipment rose from 5.8 percent in the late 1970 s to 7.5 percent in 1983, the highest level in more than twenty years. ${ }^{15}$ The special safe-harbor leasing provisions, until they were repealed, were a particularly strong stimulus to equipment investment.

Investment in producers' durable equipment was far stronger in this

15 See Feldstein and Jun (1987). The maximum potential real net return is the maximum return that firms can pay on an investment. Its variations are reflections of changes in tax rules and in the interaction of tax rules and inflation. 
recovery than in previous ones. The growth in the first year was 20.9 percent, more than twice the average of 8.1 percent in previous recoveries. For the two years, spending on producers' durable equipment rose at 17.8 percent, again more than twice the 8.8 percent average in past recoveries.

Investment in nonresidential structures actually declined sharply during the first two quarters of the expansion, pulling down the average for 1983 and for 1983-1984. But after the first two quarters, investment in nonresidential structures in each quarter grew more rapidly than the average for past recoveries.

Residential fixed investment was particularly strong at the start of the recovery and was significantly stronger than usual for both the one-year and two-year periods. About 62 percent of housing starts were for single-family units, a fraction that remained constant during the first two years of the expansion.

The clear implication of this analysis is that the rate of expansion was relatively greatest in the components of GNP that are most sensitive to interest rates and to business investment tax incentives. In comparison with past recoveries, the expansion of 1983-1984 can be characterized as led by investment rather than by either consumption or government spending. There is no evidence in the composition of spending to suggest that the very large personal tax cuts caused either consumption or total GNP to rise by more than their usual rate of increase during the early stage of a recovery.

\section{THE DIVISION OF NOMINAL GROWTH INTO INFLATION AND REAL GROWTH}

Although the 1983-1984 rise in nominal GNP can be explained without reference to the fiscal deficits, our interest in the unusually rapid expansion of real GNP requires us to look beyond monetary policy. The evidence in this section shows that the division of nominal GNP growth was more favorable than would have been expected on the basis of past experience. More specifically, we estimated the regression of the current rate of change of real GNP on the current rate of change of nominal GNP, on four lagged values of the rate of change of nominal GNP, and on four lagged values of the rate of change of real GNP. Because changes in nominal GNP equal the sum of changes in real GNP and changes in the implicit GNP price deflator, this specification is equivalent to one including lagged inflation rates instead of lagged real growth rates. The equation reflects the fact that the decomposition of changes in nominal GNP into changes in real GNP and inflation may depend on the history 
of inflation and therefore on expected future inflation. Extensions of this specification are discussed below.

We estimated this equation for the period from 1968:16 through the business cycle peak in 1981:3, and we then used the parameter estimates to forecast real GNP changes during the recovery period. We found that the actual rates of increase of real GNP during the recovery period exceeded the predicted value in every quarter. It follows, therefore, that the observed inflation (measured by the change in the implicit GNP price deflator) was lower by an equal amount in every quarter than would have been expected on the basis of the past responses to changes in nominal GNP. ${ }^{17}$

The specific results are shown in Table 4 . The first three columns show the quarterly changes in nominal GNP, real GNP, and the implicit price deflator. All figures are seasonally adjusted and expressed at quarterly rates. Column 5 presents the predicted quarterly changes in real GNP based on the equation described above, and column 6 presents the differences between the actual real GNP changes and the predicted changes.

The traditional relation between the changes in real GNP and the distributed lags of nominal GNP and inflation substantially underpredicts the strength of the real GNP increase in the 1983-1984 recovery. The prediction error is positive in every quarter. For 1983, the equation predicts 3.4 percent real GNP growth, while the actual real GNP growth was 6.4 percent. The cumulative prediction error for the four quarters of 1983 is thus 3.0 percentage points, twice the standard error of 1.5 percentage points for this prediction. For 1984, the actual real GNP growth exceeded the predicted amount by an even greater 3.6 percentage points (with a prediction standard error of 2.6 percentage points). Because of the identity linking nominal GNP, real GNP, and the implicit price deflator, it follows that the observed inflation rates were 3.0 percentage points and 3.6 percentage points lower than the predicted values for 1983 and 1984.

One possible explanation of this favorable division between inflation and real GNP is that the Federal Reserve's demonstrated commitment to reducing inflation caused a change in expectations, which in turn led to smaller price increases than would otherwise have been expected. There is no doubt that the Federal Reserve had permitted the most serious

16 The exchange rate series used below is only available (with the necessary lags) after 1967.

${ }^{17}$ Our evidence is not directly relevant to the controversy about whether the 1982 recession and 1983-1984 recovery fit the traditional, historical relationship between reductions in inflation and increases in unemployment, since we focus on the recovery period (not the recession) and study real output growth (not unemployment). 


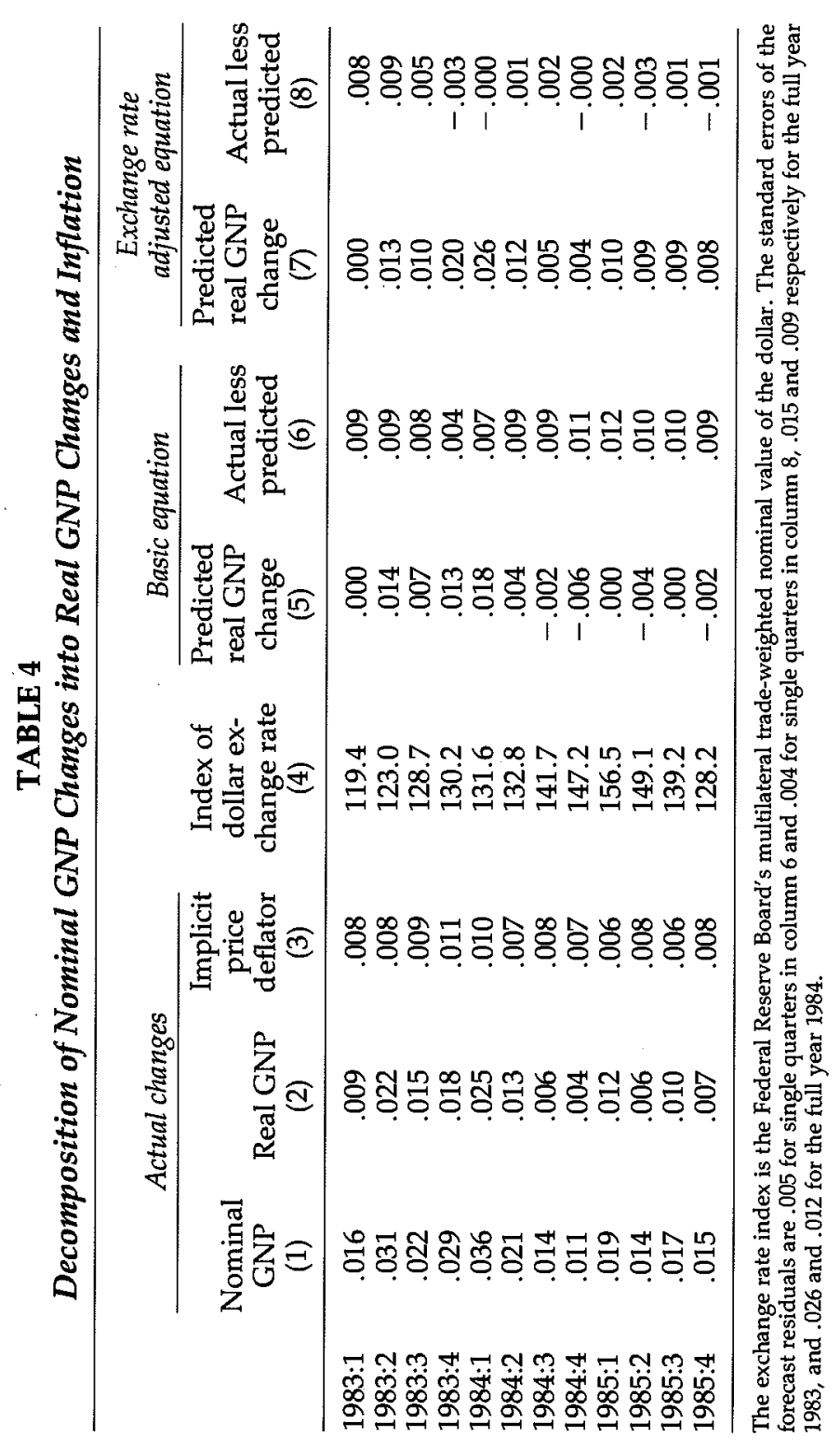


recession of the postwar period, had emphasized its commitment to controlling the monetary aggregates along an anti-inflationary path, and had permitted interest rates to reach unprecedented levels. It is difficult, however, to assess how much all of this actually changed market expectations and how much that change in expectations caused smaller increases in product prices and wages.

One reason to be skeptical about the role of changed perceptions of monetary policy is that, despite the Fed's rhetoric about slowing the growth of the monetary aggregates, M1 and M2 actually continued to increase quite rapidly. Based on the monetary statistics available at the start of 1983, the increase in M2 actually accelerated from 8.2 percent in 1978 and 1979 to 9.0 percent in $1980,10.1$ percent in 1981 , and 9.7 percent in 1982. A year later, the Federal Reserve revised the 1982 M2 growth down to 9.2 percent but reported the $1983 \mathrm{M} 2$ growth to be 11.5 percent. Although the Fed emphasized that the rapid money growth reflected regulatory changes, many financial market participants were quite skeptical. That skepticism extended also to those who watched interest rates rather than monetary aggregates and saw a sharp decline in interest rates, which they feared had been engineered by the Federal Reserve. The prospect of large budget deficits also added to the concern that the recently achieved reduction of inflation might soon be reversed.

The best direct measure of the change in the inflation expectations of informed and influential market participants is probably the survey conducted by Richard Hoey, the chief economist at Drexel Burnham Lambert (Hoey, 1988). Hoey regularly surveys the ten-year inflation expectations of a group of several hundred senior financial executives and business economists. He found that with the decline in actual inflation, the average ten-year inflation expectation fell from a high of 8.8 percent in October 1980 to 6.8 percent in April 1982 - but that it then remained essentially unchanged during the next two years, varying between 6.3 and 6.8 and ending at 6.8 percent in March 1984.

Unfortunately, since Hoey's survey did not begin until 1978, it is not possible to compare the behavior of price expectations during the 19831984 recovery with price expectations during the previous postwar recoveries. It is possible that the stability of inflation expectations during the first two years of the recent recovery is unusual and that the stability of expectations contributed to the more modest increases in prices during this period. But even if these possibilities were true, it would not be clear whether the stability of inflation expectations during the recovery period was due to faith in the Volcker-Reagan policies or simply to the fact that the observed inflation was itself so moderate during this period. More- 
over, the expected one-year inflation rates reported by Hoey were higher than the prevailing inflation rate during the entire recovery.

We believe that the most important reason for the unusually good price performance during this period was the sharp rise in the value of the dollar. ${ }^{18}$ The Federal Reserve Board's multilateral trade-weighted index of the dollar's nominal exchange value rose from 105.4 in the fourth quarter of 1981 to 122.2 in the fourth quarter of 1982 , to 130.2 in the fourth quarter of 1983, to 147.2 in the fourth quarter of 1984 .

This 40 percent increase in the dollar's exchange value directly lowered the cost of imports and put deflationary pressure on the prices of U.S. products competing with imports. The sharp rise in the nominal value of the dollar was accompanied by a 33 percent increase in the corresponding real value of the dollar. This increase in the dollar's real value reduced the demand for U.S. exports and increased the U.S. demand for imports, thereby inducing stronger domestic price competition and smaller wage increases than would otherwise have occurred. ${ }^{19}$

To assess the impact of the dollar's rise on the division of nominal GNP growth between real GNP growth and inflation, we expanded the basic equation to include the current value and four lagged values of the multilateral trade-weighted nominal exchange rate. Column 4 of Table 4 displays the exchange rate values for 1983:1 to 1985:4. Column 7 of Table 4 shows the resulting predicted values of the real GNP changes, and column 8 shows the corresponding prediction errors.

The rising dollar explains the unusual strength of real GNP and the unusually favorable inflation experience during the expansion. More specifically, inclusion of the distributed lag of exchange rate changes reduces the 1983 real GNP prediction error from 3.0 percent to 1.9 percent. For 1984, the prediction error is reduced from 3.6 percent to only 0.3 percent (relative to a standard error of 1.2 percent), and for 1985 it falls from 4.1 percent to -0.1 percent.

Some part of the dollar's strength was no doubt due to the shift in

18 Other usual suspects for changes in domestic inflation are the behavior of agricultural and energy prices. The producer price index for crude "foodstuffs and feedstuffs" was quite stable during this period, equaling 257 in 1981, 248 in 1982, 252 in 1983, and 260 in 1984. Although sharp shifts in energy prices have been important at other times during this decade, they too were relatively stable during this initial recovery period. The producer price index for crude energy prices stood at 783 in 1981, 802 in 1982, 791 in 1983, and 785 in 1984. The strong dollar no doubt also contributed to this energy stability, since the rising dollar automatically increased the cost in marks and yen and other currencies of oil and other imported energy products.

19 On the effect of the dollar's strength on U.S. inflation during this period, see Sachs (1985). 
monetary policy and the fall in inflation expectations that accompanied the recession and the observed price decline. The tight monetary policy in 1981 temporarily raised expected real long-term interest rates and thereby made dollar securities more attractive. The Hoey surveys show that the expected real pretax yield on ten-year government bonds rose from a low of only 1.6 percent in June and July 1980 to a high of 8.3 percent in September 1981. But by late 1982, the expected real interest rate was down to about 4 percent, and it stayed at that level through mid-1983. The easing of monetary policy in the second half of 1982 reduced nominal interest rates and thereby accelerated the decline in real interest rates.

Although post-1982 monetary policy may have continued to contribute to a strong dollar by reducing the uncertainty of future inflation, we believe that the primary reason for the dollar's continued rise was the change in U.S. fiscal policy. The budget deficit climbed from 2.6 percent of GNP in 1981 to 4.1 percent in 1982 and to 6.3 percent in 1983, and it then stabilized at over 5 percent of GNP for the next three years. Although there remains much academic controversy about the link between budget deficits and interest rates, we believe the contemporaneous budget deficits and especially the expected future deficits raised real interest rates and increased the attractiveness of dollar investments. ${ }^{20}$

There can be little doubt that real interest rates did rise during this period. The nominal interest rate on ten-year Treasury bonds remained essentially unchanged, starting at 10.5 percent in December 1982, rising to 11.8 percent by December 1983 , and then falling to 11.5 percent in December 1984; the inflation rate, as measured by the GNP deflator, fell from 5.2 percent in 1982 to 3.6 percent in 1983 and to 3.4 percent in 1984 . The Hoey measure of expected real pretax yields on ten-year Treasury bonds rose from 3.9 percent in December 1982 to 5.3 percent in January 1984 and to 7.5 percent in May 1984, before subsiding to 5.9 percent in December 1984.

The leading alternative to current and future budget deficits as the explanation of the rise in real interest rates is the increased investment demand that resulted from the 1981 changes in tax rules. Although we believe that those tax changes did increase investment demand (see Feldstein, 1987, and Feldstein and Jun, 1987), we do not believe that this increase in investment demand was nearly as important as the sharp climb in the budget deficit. The increase in the cyclically-adjusted deficit from 1.8 percent of cyclically-adjusted GNP in 1981 to 3.7 percent in 1983

${ }^{20}$ In this emphasis on expected future budget deficits as the cause of the high real longterm interest rates and the strong dollar, we agree with the analysis of Blanchard (1981), Branson (1985), and Economic Report of the President (1984). 
and 4.6 percent in 1985 was substantially bigger than the increase in fixed investment induced by the change in tax policy.

But this paper is not the place to resolve the controversy about the relative importance of expected future budget deficits and investment incentives as causes of the rise in real interest rates and the dollar. ${ }^{21}$ The important matter for current purposes is that these two fiscal changesthe budget deficit and the increased investment incentives-increased the attractiveness of dollar investments and thereby raised the value of the dollar. The stronger dollar in turn meant that the inflation rate was lower than it otherwise would have been. The expansion of nominal GNP was therefore divided in a more favorable way between inflation and real GNP.

\section{CONCLUSION}

The evidence presented in this paper contradicts the popular view that the 1983-1984 economic recovery was the result of a consumer boom financed by reductions in the personal income tax. We also find no support for the proposition that the recovery reflected an increase in the supply of labor induced by the reduction in personal tax rates.

The timing of the expansion and the composition of the real output changes make it clear that the primary cause of increased output was the shift to a more expansionary monetary policy that occurred in 1982. In particular, short-term nominal interest rates fell throughout the period, while nominal GNP rose, indicating that the supply of money was increasing faster than the demand for money. Formal tests of the impact of monetary and fiscal policy imply that the increased budget deficits played no role in the rise of nominal GNP. Any positive effect of the deficits on total demand was presumably offset by the contractionary effects of higher interest rates.

An important distinguishing feature of the 1983-1984 recovery was the unusually rapid increase of business investment while consumer spending and federal government purchases of goods and services were not unusually strong. This pattern also points to the role of monetary policy and of the enhanced investment incentives contained in the 1981 tax reform.

The expansion of total demand in 1983-1984 was divided more favorably between real output and inflation than would have been expected on the basis of past experience. Our analysis shows that this important

21 Feldstein (1986b) provides estimates of the impact of the expected budget deficits and changes in tax rules on the dollar-mark value and concludes that the deficit effect is substantial but that the effect of the tax incentives cannot be discerned in the data. 
difference can be explained by the sharp increase in the value of the dollar during this period. Although the strong dollar depressed exports and induced a rise in imports, its net effect on total real output was favorable, because it reduced the rate of inflation and thereby permitted more of the rise in nominal GNP to be channeled into real GNP.

The dollar's rise and the resulting fall in inflation also may have induced the Federal Reserve to permit a more expansionary monetary policy during this period than it otherwise would have. To that extent, our analysis understates the impact of the strong dollar on the pace of real expansion.

Because of the expansionary fiscal policy, the dollar rose sharply during this period despite the easing of monetary policy. The increased budget deficit and the enhanced incentives for business investment raised real interest rates and thus made U.S. securities more attractive to foreign and domestic portfolio investors. The result was an increased value of the dollar.

The expansionary fiscal policy did contribute to the greater-thanexpected rise of real GNP in 1983-1984, but it did so through an unusual channel. The fiscal expansion raised output because it caused a favorable supply shock, not because it was a traditional stimulus to demand. The budget deficit and the investment incentives were expansionary in the short run because, by causing a rise of the dollar, they reduced inflation and thus permitted a faster growth of real GNP.

\section{REFERENCES}

Andersen, Leonall C., and Jerry L. Jordan. 1968. Monetary and fiscal actions: A test of their relative importance in economic stabilization. Federal Reserve Bank of St. Louis Review 50: 11-24.

Blanchard, Olivier J. 1981. Output, the stock market, and interest rates. American Economic Review 71: 132-43.

Blinder, Alan S., and Robert M. Solow. 1974. Analytical foundations of fiscal policy. In The economics of public finance. Washington, D.C.: Brookings Institutions.

Branson, William H. 1985. Causes of appreciation and volatility of the dollar. In The U.S. dollar-recent developments, outlook, and policy options. Kansas City: The Federal Reserve Bank of Kansas City.

Economic report of the president. 1984. Washington, D.C.: Government Printing Office.

Feldstein, Martin. 1986a. Supply-side economics: Old truths and new claims. American Economic Review 76: 26-30.

. 1986b. The budget deficit and the dollar. In NBER macroeconomics annual, 1986, ed. S. Fischer. Cambridge, MA: MIT Press.

. 1987. Tax rules and business investment. In Taxes and capital formation, ed. M. Feldstein. Chicago: University of Chicago Press. 
Feldstein, Martin, and Joosung Jun. 1987. The effects of tax rules on nonresidential fixed investment: Some preliminary evidence from the 1980s. In The effects of taxation on capital accumulation, ed. M. Feldstein. Chicago: University of Chicago Press.

Fisher, Franklin. 1970. Tests of equality between sets of coefficients in two linear regressions: An expository note. Econometrica 38: 361-66.

Friedman, Benjamin M. 1986. Money, credit and interest rates in the business cycle. In The American business cycle: Continuity and change, ed. R. J. Gordon. Chicago: University of Chicago Press.

- 1988. Lessons on monetary policy from the 1980s. Journal of Economic Perspectives 2: 51-72.

Hoey, Richard B. 1988. Decision-makers poll. New York: Drexel Burnham Lambert.

Holloway, Thomas M. 1986. The cyclically adjusted federal budget and federal debt: Revised and updated estimates. Survey of Current Business 66: 11-17.

McCallum, Bennett T. 1986. Monetary vs. fiscal policy effects: A review of the debate. In The monetary vs. fiscal policy debate, ed. R. W. Hafer. Totowa, NJ: Rowman and Allanheld.

Pindyck, Robert S., and Daniel L. Rubinfeld. 1981. Econometric models and economic forecasts. New York: McGraw-Hill.

Poole, William. 1988. Monetary policy lessons of recent inflation and disinflation. Journal of Economic Perspectives 2: 73-100.

Sachs, Jeffrey D. 1985. The dollar and the policy mix: 1985. Brookings Papers on Economic Activity 16: 117-97. 

'

$$
\text { , }
$$

